\title{
N and P limitation of benthos abundance in the Nechako River, British Columbia
}

\author{
Chris J. Perrin and John S. Richardson
}

\begin{abstract}
Additions of inorganic $\mathrm{N}$ and $\mathrm{P}$ to replicated stream mesocosms were used to test the hypothesis that production of the benthic food web in the flow-controlled Nechako River, B.C., was N and P limited. N, P, and N + P additions were contrasted with controls to determine the responses of periphyton and macroinvertebrates over a 33-day period in late spring. Periphyton accrual under $\mathrm{N}+\mathrm{P}$ addition was greater than two times that of the controls, and $\mathrm{N}$ alone produced a moderate increase. Periphyton showed relatively little response to $\mathrm{P}$ addition compared with controls. Macroinvertebrates, especially orthocladiine midges and mayflies, increased in density under $\mathrm{N}$ or $\mathrm{N}+\mathrm{P}$ additions, in contrast with $\mathrm{P}$ additions and controls. Increased emergence rates of adult aquatic insects from the mesocosms were consistent with increases observed in benthic invertebrates. The results showed nutrient limitation of benthic productivity and that algal and benthic invertebrate responses were closely coupled. $\mathrm{N}$ was most limiting, but with additions of inorganic $\mathrm{N}$ as low as $10 \mu \mathrm{g} \cdot \mathrm{L}^{-1}, \mathrm{P}$ became limiting. The benthic invertebrates that increased most in abundance corresponded to the predominant prey in chinook salmon (Oncorhynchus tshawytscha) fry diets at the time of the experiment.
\end{abstract}

\begin{abstract}
Résumé : Nous avons ajouté du N et du P inorganiques dans une série de mésocosmes lotiques pour valider l'hypothèse selon laquelle la production de la chaîne alimentaire benthique dans la rivière Nechako, un cours d'eau de Colombie-Britannique à débit contrôlé, était limitée en $\mathrm{N}$ et en $\mathrm{P}$. Les effets des ajouts de $\mathrm{N}$, de $\mathrm{P}$ et de $\mathrm{N}+\mathrm{P}$ ont été comparés à des valeurs témoins afin de déterminer les réponses du périphyton et des macroinvertébrés sur une période de 33 jours de la fin du printemps. L'accroissement du périphyton pour un ajout de $\mathrm{N}+\mathrm{P}$ était plus du double que pour les témoins, et l'ajout de $\mathrm{N}$ seul a entraîné une augmentation modérée. Par contre, l'effet d'un ajout de P a eu relativement peu d'effet sur le périphyton. La densité des macroinvertébrés, particulièrement les chironomidés orthocladiinés et les éphéméroptères, a augmenté en cas d'ajout de $\mathrm{N}$ ou de $\mathrm{N}+\mathrm{P}$, mais pas en cas d'ajout de $\mathrm{P}$ ni dans les milieux témoins. Les taux accrus d'émergence observés chez les insectes aquatiques adultes des mésocosmes étaient conformes aux augmentations observées chez les invertébrés benthiques. Les résultats ont montré que la production benthique était limitée par les éléments nutritifs et que les réactions des algues et des invertébrés benthiques étaient étroitement liées. C'est l'azote qui était l'élément le plus limitant; pour des ajouts de $\mathrm{N}$ inorganique de seulement $10 \mu \mathrm{g} \cdot \mathrm{L}^{-1}$, P est devenu limitant. Les invertébrés benthiques dont l'abondance a le plus augmenté correspondaient aux principales proies des alevins du saumon quinnat (Oncorhynchus tshawytscha) au moment de l'expérience.

[Traduit par la Rédaction]
\end{abstract}

\section{Introduction}

Growth rates and biomass of several trophic levels in large and small streams are known to increase with the addition of inorganic nutrients. Peterson et al. (1983), Perrin et al. (1987), and Bothwell (1989) showed that additions of P to P-deficient streams can increase the growth and biomass of periphytic algae. The concentration of added $\mathrm{PO}_{4}-\mathrm{P}$ that saturates $\mathrm{P}$ deficient growth can be $<1 \mu \mathrm{g} \cdot \mathrm{L}^{-1}$ (Bothwell 1989), but the concentration that saturates the accrual of areal biomass is higher due to diffusion effects within the algal mat (Bothwell 1989; Stevenson and Glover 1993). With the response by algae to nutrient augmentation in rivers, there can be an increase in

Received August 12, 1996. Accepted April 9, 1997.

J13603

Chris J. Perrin ${ }^{1}$ and John S. Richardson. ${ }^{2}$ Limnotek Research and Development Inc., 4035 West 14th Avenue, Vancouver, BC V6R 2X3, Canada.

1 Author to whom all correspondence should be addressed. e-mail: cperrin@istar.ca

2 Present address: British Columbia Environment and Department of Forest Sciences, University of British Columbia, Vancouver, BC V6T 1Z4, Canada. benthic invertebrate abundance (Johnston et al. 1990; Hart and Robinson 1990), largely due to feeding on the more abundant food supply in periphyton (Hershey et al. 1988) which improves invertebrate survival (Mundie et al. 1991). These additions of nutrients that limit algal growth will favour energy transfer based on autotrophy rather than heterotrophy (Peterson et al. 1985) and can produce an increase in the biomass and yield of fish (Johnston et al. 1990; Deegan and Peterson 1992) due to increased availability of the food organisms.

Because of the potential for increased salmonid yield, nutrient addition to rivers has been considered a technique to mitigate for possible losses of fish production or habitat in large projects involving flow diversion and impoundment. In the planning for one of these projects, known as the Kemano Completion Project in British Columbia, Canada, nutrient addition was considered an option to mitigate potential impacts on chinook salmon (Oncorhynchus tshawytscha) from the diversion of water from the Nechako River, a large tributary of the Fraser River in British Columbia, by the Nechako Fisheries Conservation Program (NFCP). In 1952, the Kenney Dam was constructed on the Nechako River, approximately $280 \mathrm{~km}$ upstream of its confluence with the Fraser River (Fig. 1). Up to $60 \%$ of the flow in an average inflow year was diverted to turbines located at Kemano on the west coast of British 
Fig. 1. Study site located within the Nechako River system.

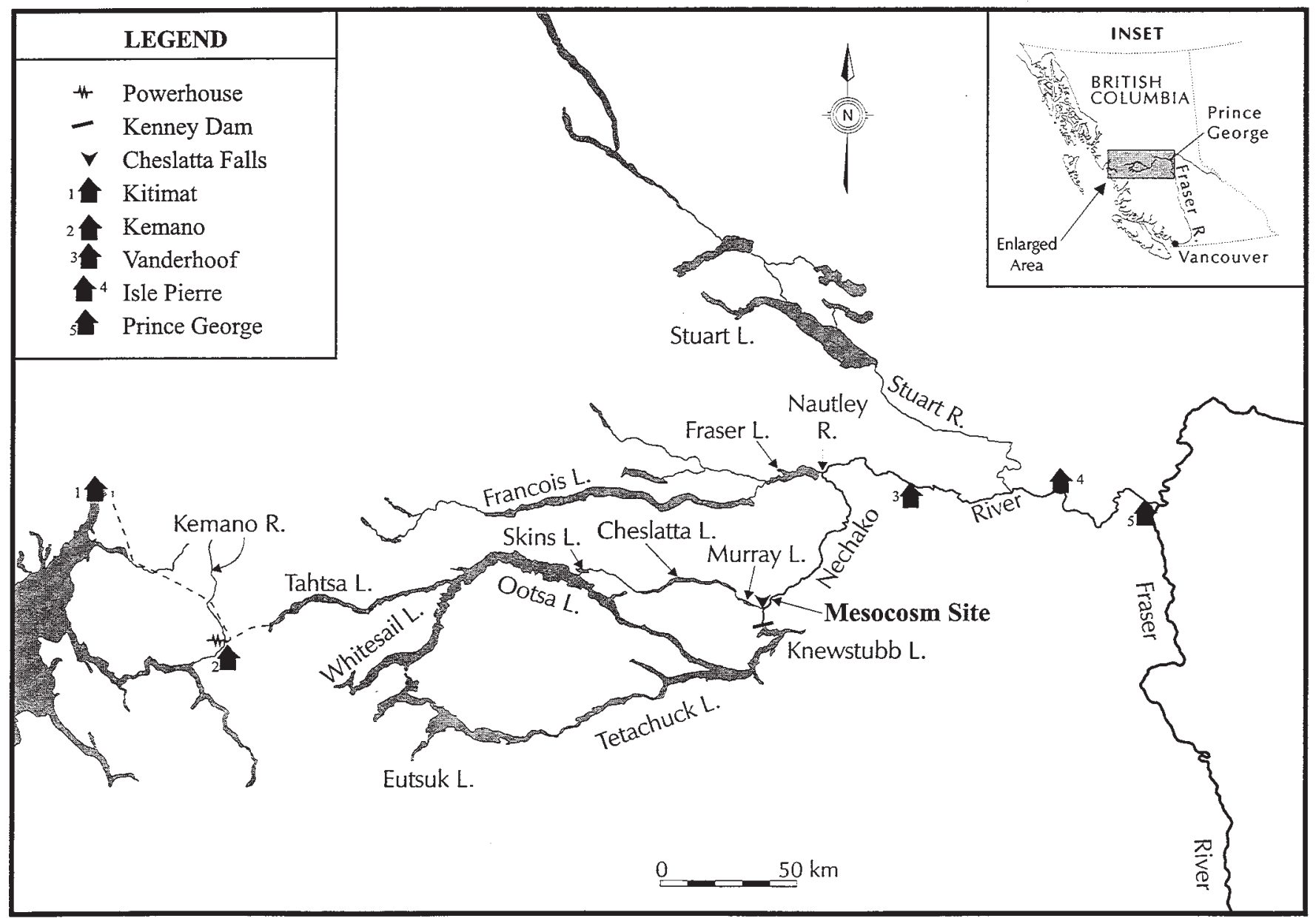

Columbia for hydropower generation. In 1978, flows were further reduced and, beginning in 1980, were determined by legal requirements negotiated between the Department of Fisheries and Oceans (DFO) and the developer Alcan Ltd. The Kemano Completion Project was intended to divert additional water for power generation, further reducing the flow in the Nechako River. The project included the release of cool hypolimnetic water from the reservoir to the Nechako River at times of upstream migration of sockeye salmon (Oncorhynchus nerka) to the Stuart River, which empties into the Nechako River $80 \mathrm{~km}$ upstream of the confluence of the Nechako and Fraser rivers. With the release of hypolimnetic water for 1.2 months each summer, the mean daily temperature would be expected to drop by up to $6^{\circ} \mathrm{C}$ in the upper river. Predictions that cooler water would reduce the growth rates of chinook by $25 \%$ (Slaney et al. 1994) and that reduced flow could lead to lower recruitment rates (Bradford 1994) led the Nechako Fisheries Conservation Program to require mitigation techniques to be applied, if needed, to sustain the upper Nechako chinook population. Fertilization in combination with habitat improvement was proposed as one mitigation approach and tested using in situ trials in upper reaches during 1988-1991 (Slaney et al. 1994).

Although the addition of a growth-limiting nutrient to a river can produce a trophic response culminating in increased fish biomass (Johnston et al. 1990; Deegan and Peterson 1992), this result was not observed in the Nechako River during in situ fertilization trials. Nutrient augmentation producing $20 \mu \mathrm{g}$ dissolved inorganic $\mathrm{N}\left(\mathrm{NO}_{3}{ }^{-}-\mathrm{N}+\mathrm{NH}_{4}{ }^{+}-\mathrm{N}(\mathrm{DIN})\right) \cdot \mathrm{L}^{-1}$ and $5 \mu \mathrm{g} \mathrm{PO}_{4}{ }^{2-}-\mathrm{P} \cdot \mathrm{L}^{-1}$ at full mixing in the upper river in 1989 failed to increase the size of the juvenile chinook (Slaney et al. 1994). Slaney et al. (1994) presented two hypotheses to explain the influence of other factors on this result. First, large movements of chinook fry and fingerlings in the upper Nechako River prevented the capture of fish that may have responded to any increase in availability of food in the fertilized reaches. This possibility was supported with evidence from mark and recapture studies showing that chinook fry and fingerlings did not remain in specific habitats during the summer growing season (Slaney et al. 1994). This finding meant that many fish that may have benefitted from a trophic response to fertilization may have escaped the sampling areas and were not included in the analysis of a treatment effect. The second hypothesis was that the captured chinook fry and fingerlings were growing at maximum temperature-specific rates and that fish growth was not limited by food availability. Growth modelling studies by Slaney et al. (1994) suggested that the fish were growing at close to maximum rates in May, but the rates were progressively suboptimal from June through September (Slaney et al. 1994), indicating increasing 
importance of food deficiency on growth as the summer growing season progressed. Although not explored by Slaney et al. (1994), a further hypothesis was that the fertilization did not produce an increase in abundance of invertebrates available for chinook fry and fingerlings. If the latter explanation were true, it would be unique among experiments in which responses to fertilization have been examined.

In this paper, we have examined the last hypothesis by reporting results of a mesocosm-scale experiment to quantify change in periphytic algae and benthic invertebrate composition and abundance with additions of inorganic N and P. Replicated flow-through troughs were established on the banks of upper Nechako River in which additions of $\mathrm{N}$ alone, $\mathrm{P}$ alone, and $\mathrm{N}+\mathrm{P}$ were tested against an untreated control. The experiment was run at a location upstream of any other in situ testing described by Slaney et al. (1994) that was occurring in the river at the time. In a trough mesocosm, biological and chemical processes are integrated, providing invertebrates with natural food levels and environmental conditions as they are in the natural river. This simulation allows for replication and high levels of statistical power that enable considerable extrapolation of findings to larger reaches (Perrin et al. 1992). Our main objective was to quantify the change in the composition and abundance of benthic invertebrates, particularly those comprising the diet of juvenile chinook, that occurs in the Nechako River with addition of $\mathrm{N}$ and $\mathrm{P}$ alone and in combination.

\section{Materials and methods}

The existing Nechako River originates at Murray Lake, $2.6 \mathrm{~km}$ upstream of Cheslatta Falls $\left(53^{\circ} 38^{\prime} \mathrm{N}, 124^{\circ} 58^{\prime} \mathrm{W}\right)$ in central British Columbia, Canada (Fig. 1). Water flows entering Murray Lake are regulated at the Skins Lake spillway which controls water discharge from Ootsa Lake, a basin of the Nechako Reservoir originally formed by impoundment of the Nechako River by construction of the Kenney Dam in 1952 (Fig. 1). Release of water at the spillway is determined by legal requirements augmented by variation in annual snowmelt and local rainfall. The mean annual flow at Cheslatta Falls is $61 \mathrm{~m}^{3} \cdot \mathrm{s}^{-1}$ and the natural spring freshet has been shifted by flow regulation from spring to midsummer to provide cooling flows of $280-290 \mathrm{~m}^{3} \cdot \mathrm{s}^{-1}$ to protect a major sockeye run that uses the Nechako as a migration route into the Nautley and Stuart rivers, 90 and $190 \mathrm{~km}$, respectively, downstream of Cheslatta Falls (Fig. 1). The Nechako River empties into the Fraser River at Prince George, $260 \mathrm{~km}$ downstream of Cheslatta Falls.

The trough apparatus was installed at the river margin in a canyon approximately $4.5 \mathrm{~km}$ downstream from Cheslatta Falls. This site provided sufficient hydraulic head for a gravity-based water supply. Access to the site was by jet boat launched $14.5 \mathrm{~km}$ downstream of Cheslatta Falls. Maximum water depth across the wetted width of the Nechako River at the trough site was $0.5 \mathrm{~m}$ and the current velocity was about $0.6 \mathrm{~m}^{3} \cdot \mathrm{s}^{-1}$. Mean flow of the river was regulated to $60 \mathrm{~m}^{3} \cdot \mathrm{s}^{-1}$ for the duration of the experiment (May and June 1990). Water temperature, determined from hourly readings $19 \mathrm{~km}$ downstream of the Kenney Dam, was between 8 and $14^{\circ} \mathrm{C}$, with temperature generally increasing throughout the experiment.

The 16 mesocosms were flow-through troughs (each $1.52 \mathrm{~m}$ long $\times 0.2 \mathrm{~m}$ wide) that were fabricated from $0.64-\mathrm{cm}$ clear Plexiglas and assembled on a series of joists laid at the river margin. The design followed that originally reported by Mundie et al. (1991, see their fig. 1) and subsequently modified for use in chemical manipulation studies (Perrin et al. 1992; Richardson and Perrin 1994). Water and biota carried in suspension in the Nechako River were supplied via gravity through a $15.24-\mathrm{cm}$-diameter PVC pipe laid upstream over a distance of $500 \mathrm{~m}$, providing a head of $0.79 \mathrm{~m}$ and water flow of about $8 \mathrm{~L} \cdot \mathrm{s}^{-1}$. The apparatus consumed a minimum of $5 \mathrm{~L} \cdot \mathrm{s}^{-1}$. The pipeline was fitted to a head tank and water was delivered to each trough through a standpipe assembly that was used to adjust water flow in each trough to $0.3 \mathrm{~L} \cdot \mathrm{s}^{-1}$.

Nutrient solutions were introduced into the upstream end of each treated trough by siphoning concentrated solutions of $\mathrm{NH}_{4} \mathrm{NO}_{3}$ and $\mathrm{KH}_{2} \mathrm{PO}_{4}$ at a rate of $0.5 \mathrm{~mL} \cdot \mathrm{min}^{-1}$ (calibrated daily) from 4-L glass Mariotte bottles through microbore tubing. The solutions were prepared from reagent-grade chemicals and distilled water. Nutrients were mixed with river water in a mixing chamber located at the upstream end of each trough.

Downstream of the mixing chamber was a $1.2-\mathrm{m}$ section within which 2-cm-diameter drain rock was laid to a depth of $5 \mathrm{~cm}$. This section provided substrata for the colonization and growth of benthic invertebrates. Downstream of the gravel was a $0.32-\mathrm{m}$ section that was fitted with a sheet (1.2-cm thickness) of open-cell styrofoam (as reported by Perrin et al. 1987) that provided a surface for the sampling of periphyton biomass. The gravel and styrofoam sections were separated with a 7-cm-high baffle that produced a water depth of $7 \mathrm{~cm}$ over the gravel and a surface current velocity of $5 \mathrm{~cm} \cdot \mathrm{s}^{-1}$. Water leaving the gravel section flowed over the baffle and dropped onto the styrofoam surface. The water then flowed in a laminar pattern over the styrofoam at a depth of $1 \mathrm{~cm}$.

The experiment included measures of change in periphyton accrual and species composition, as well as macroinvertebrate density, drift rate, and adult emergence as a function of nutrient augmentation. Four conditions were additions of DIN $\left(\mathrm{NO}_{3}-\mathrm{N}+\mathrm{NH}_{4}+-\mathrm{N}\right)$ to achieve a fully mixed concentration of $10 \mu \mathrm{g} \cdot \mathrm{L}^{-1}$, soluble reactive $\mathrm{P}$ (SRP) at $5 \mu \mathrm{g} \cdot \mathrm{L}^{-1}$, and the combination of $\mathrm{N}$ and $\mathrm{P}$ contrasted with a control having no nutrient additions. Although these nutrient doses were lower than those reported in other tests of nutrient deficiency in streams (Peterson et al. 1983; Mundie et al. 1991; Slaney et al. 1994), they do exceed levels known to saturate both $\mathrm{N}$ - and P-limited growth of periphyton in rivers (Bothwell 1989, 1992). Each of the three treatments and the control were replicated four times producing a layout of 16 experimental units randomly assigned to treatments. Water flows were adjusted and nutrient additions started on May 24, 1990. All flows were stopped with the completion of all sampling on June 26, 1990.

Water samples were collected weekly, filtered in the field, and analyzed for concentrations of $\mathrm{NH}_{4}{ }^{+}, \mathrm{NO}_{3}{ }^{-}+\mathrm{NO}_{2}{ }^{-}$, and SRP within $48 \mathrm{~h}$ of sample collection. The sum of the concentrations of $\mathrm{NO}_{3}^{-}$ $-\mathrm{N}+\mathrm{NO}_{2}{ }^{-}-\mathrm{N}$ and $\mathrm{NH}_{4}{ }^{+}-\mathrm{N}$ represented DIN. In this paper, $\mathrm{NO}_{3}{ }^{-}-\mathrm{N}+$ $\mathrm{NO}_{2}^{-}-\mathrm{N}$ is simplified to $\mathrm{NO}_{3}^{-}$and total ammonia $\left(\mathrm{NH}_{3}+\mathrm{NH}_{4}^{+}\right)$to $\mathrm{NH}_{4}^{+}$.

Periphyton accrual began on May 24 with the installation of clean styrofoam substrata. In weekly intervals up to June 26 (33 days), a 2 -cm-diameter core of the styrofoam and adhering biomass was removed from each trough and frozen at $-15^{\circ} \mathrm{C}$ for shipment to the laboratory. The biomass was analyzed for chlorophyll $a$ concentration using the fluorometric procedure after extraction in $90 \%$ acetone (Holm-Hansen et al. 1965; Nusch 1980). On the final sampling day, an additional core was extracted from each substratum and preserved in Lugol's solution for taxonomic identification and enumeration. Counts of cells containing cytoplasm were made at $500 \times$ magnification in Utermohl chambers. A minimum of 100 individuals of the most abundant species and a total of 300 cells in total were counted.

Insect drift from the troughs (emigration) was collected for 24-h periods on June 11, 18, and 25. The samples were collected in buckets that had openings covered with $253-\mu \mathrm{m}$-mesh Nitex netting. One bucket was fitted to the end of each trough and continuously filtered all water to the $253-\mu \mathrm{m}$ size fraction. Contents were preserved in 5\% formalin. All animals were separated from the algae and other detritus using a dissecting microscope at 6.4-16× magnification. Sorted samples were preserved in $70 \%$ ethanol for counting and identification.

An insect emergence trap that was identical in design to that 
Table 1. Mean SRP concentrations $\left(\mu \mathrm{g} \cdot \mathrm{L}^{-1}\right)( \pm 1 \mathrm{SE}$ in parentheses) in each treatment by week of sample collection.

\begin{tabular}{lcccr}
\hline Date & Control & $\mathrm{N}$ alone & $\mathrm{P}$ alone & $\mathrm{N}+\mathrm{P}$ \\
\hline May 31 & $17.5(4.4)$ & $10.8(4.2)$ & $16.3(8.9)$ & $15.0(2.7)$ \\
June 7 & $17.8(3.8)$ & $10.3(0.6)$ & $10.3(3.0)$ & $12.8(2.5)$ \\
June 14 & $3.0(0.7)$ & $1.0(0)$ & $2.8(0.3)$ & $3.5(1.3)$ \\
June 21 & $2.8(1.1)$ & $3.8(1.2)$ & $6.0(1.1)$ & $5.8(0.5)$ \\
June 28 & $3.0(2.0)$ & $2.0(1.0)$ & $5.7(3.3)$ & $3.0(1.0)$ \\
\hline \multicolumn{5}{l}{ Note: On all dates, $\mathrm{NO}_{3}{ }^{-}-\mathrm{N}$ and $\mathrm{NH}_{4}{ }^{+}-\mathrm{N}$ concentrations were } \\
each <5 $\mu \mathrm{g} \cdot \mathrm{L}^{-1}$.
\end{tabular}

reported by Mundie et al. (1991) covered the top of each trough. Inside each trap were two longitudinal channels into which a solution of $5 \%$ formalin plus a wetting agent was poured to a depth of $1.5 \mathrm{~cm}$. Emerging insects entered the chambers and were captured in the preservative. The traps were emptied weekly.

At the end of the experiment on June 26, zoobenthos was collected by washing the entire contents of each trough into a $250-\mu \mathrm{m}$ Nitex net that was secured to the outlet. The gravel in each trough was agitated by hand for a standard period of $5 \mathrm{~min}$. Retained benthos was preserved in $10 \%$ formalin. In the laboratory, all samples were subsampled and enumerated using procedures described in Mundie et al. (1983). Briefly, the sample material was settled into a "honeycomb" of 82 glass tubes $(2.2 \mathrm{~cm}$ in diameter, $9.5 \mathrm{~cm}$ high) standing in a bucket half full of water. Ten tubes were drawn at random and enumerated at $40 \times$ magnification. Statistical analyses to examine treatment effects considered the mean count from the 10 tubes as a single replicate. Total numbers by taxa were determined by extrapolating tube counts based on the proportion of area in the settlement bucket that was enumerated. Aquatic invertebrates were identified to the lowest reliable taxonomic level (usually genus) using appropriate keys.

Statistical analysis of the data were by one-way ANOVA (four treatment levels) for measures taken at the end of the experiment (benthos). For variables that were repeatedly measured (periphyton biomass, adult insect emergence, drift), we tested the effect of treatment (four levels) and time (four dates) on the variable using a twoway, nested ANOVA. The $F$-test for the treatment effect was calculated using the trough-within-treatment factor as the error term which controlled for date, but did not inflate the error term, i.e., date was a repeated measure. Significant treatment differences were tested with prior contrasts or a posteriori tests (Tukey's). Some of the data (benthic densities) were log transformed to improve homogeneity of variance.

\section{Results}

\section{Nutrients and periphyton}

Concentrations of SRP in trough outflow water were relatively high and variable early in the experiment (May 31 and June 7), but they declined by June 14 (Table 1). On all dates, concentrations of $\mathrm{NO}_{3}^{-}$and $\mathrm{NH}_{4}{ }^{+}$were each $<5 \mu \mathrm{g} \mathrm{N} \cdot \mathrm{L}^{-1}$ in all troughs. With the exception of samples from June 21, SRP concentrations measured in troughs receiving the addition of $\mathrm{N}$ alone were lower than those in the control troughs.

Molar N:P supply ratios could not be determined with accuracy because of the inability to detect concentrations of the inorganic $\mathrm{N}$ species. If we assign the combined detection limit of $5 \mu \mathrm{g} \mathrm{N} \cdot \mathrm{L}^{-1}$ for each of $\mathrm{NO}_{3}{ }^{-}$and $\mathrm{NH}_{4}{ }^{+}$, to provide an assigned value of $10 \mu \mathrm{g} \cdot \mathrm{L}^{-1}$, the molar $\mathrm{N}: \mathrm{P}$ supply ratios ranged from 1.2 (control on June 7) to 10.1 ( $\mathrm{N}$ alone troughs on June 14). Actual supply ratios were probably higher than these
Fig. 2. Time course changes in chlorophyll $a$ concentrations $( \pm 1$ $\mathrm{SE}$ ) with additions of $\mathrm{N}+\mathrm{P}, \mathrm{P}$ alone at $5 \mu \mathrm{g} \cdot \mathrm{L}^{-1}$, and $\mathrm{N}$ alone at 10 $\mu \mathrm{g} \cdot \mathrm{L}^{-1}$ in the trough mesocosms in the Nechako River.

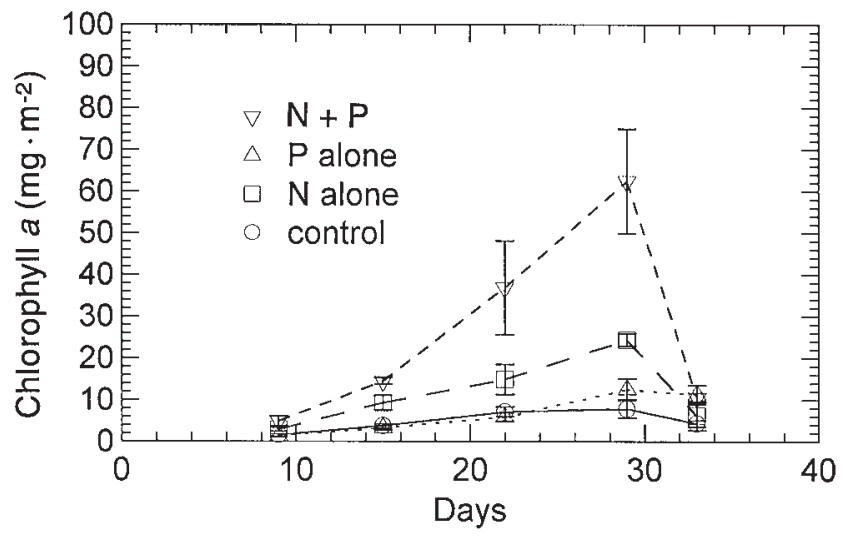

values, but even so, they were in a range where most algal species could be limited by $\mathrm{N}$ and fewer by $\mathrm{P}$ based on optimum N:P supply ratios reported by Rhee and Gotham (1980) and Healey (1985). In the control troughs, these approximate ratios ranged from 1.3 measured on June 7 to 7.9 measured on June 21. These values are also in the range where the growth of most taxa would be expected to be potentially limited by $\mathrm{N}$.

There was a significant periphyton chlorophyll $a$ response to the nutrient additions (repeated measures ANOVA, $F_{3,12}=$ 94.4, $p<0.0001$; Fig. 2). The $\mathrm{N}+\mathrm{P}$ addition produced a peak chlorophyll $a$ concentration of $64 \mathrm{mg} \cdot \mathrm{m}^{-2}$, which was greater than twice that of the response to $\mathrm{N}$ addition and greater than the $\mathrm{P}$ additions and controls. The $\mathrm{N}+\mathrm{P}$ addition produced a significant increase in chlorophyll $a$ concentration over the other two treatments and control (all with $p<0.0001$ ). The greater chlorophyll $a$ concentration with $\mathrm{N}+\mathrm{P}$ versus $\mathrm{N}$ alone indicates that accrual was limited by $\mathrm{P}$ with $\mathrm{N}$ added alone. Addition of $\mathrm{N}$ alone produced a significant increase in periphyton accrual over $\mathrm{P}$ addition $(p<0.03)$ and the control $(p=$ $0.002)$. There was no significant difference in chlorophyll $a$ concentration between the $\mathrm{P}$ addition and control $(p>0.5)$.

After 29 days of biomass accrual, sloughing occurred in all troughs producing a large decline in areal biomass, particularly in treatments receiving $\mathrm{N}$ and $\mathrm{N}+\mathrm{P}$ additions (Fig. 2) despite continuous enrichment. Periphyton chlorophyll $a$ concentration in the $\mathrm{N}+\mathrm{P}$ treatment declined by $83 \%$ within 4 days, and in troughs receiving only $\mathrm{N}$ additions, it declined by an average of $75 \%$ over the same period. In comparison, chlorophyll $a$ concentration in the troughs receiving $\mathrm{P}$ declined by only $10 \%$ over the same period.

The relative composition of periphyton assemblages was similar for all treatments. Diatoms were the most common algae in all troughs, making up $80-90 \%$ of the algal abundance (Table 2). Chlorophytes represented 10-20\% of the communities and the cyanophyte Anabaena sp. represented only $0.4-0.5 \%$ of communities across all treatments. Synedra sp. and Fragilaria sp. were the most common diatom taxa, representing $57.5-62.5 \%$ and $11.8-15.8 \%$ of the diatom component, respectively.

Insect emergence

The most common taxon among the emergent adult insects 
were the midges (Chironomidae) which constituted 60-76\% of all adults caught in the emergence traps (Table 3). Other taxa represented in the emergence trap collections were caddisflies (Trichoptera, 12-26\%), stoneflies (Plecoptera, 4-8\%), mayflies (Ephemeroptera, 2-3.5\%), and a few rarely encountered taxa (Table 3). The chironomid adults were not identified beyond family. Trichoptera were primarily Hydroptilidae and Rhyacophilidae, the stoneflies were mostly Chloroperlidae and Perlodidae, and mayflies were primarily represented by the genera Baetis and Ephemerella. Total numbers of insects per trough emerging over the 33 days of emergence collection ranged from a minimum of 148 in the control to 238 in troughs receiving the $\mathrm{N}$ additions (Table 3 ).

Total numbers of emerging insects increased severalfold through time ( $p<0.002$; Fig. 3 ) across all treatments (no significant date by treatment interaction, $p>0.30)$. The $F$-test for a treatment effect was significant (repeated measures ANOVA, $p<0.04$ ), and the addition of $\mathrm{N}$ alone produced more animals than the control $(p<0.02)$, as did the addition of $\mathrm{N}+\mathrm{P}(p<0.03)$. The addition of $\mathrm{P}$ alone did not result in more insects $(p>0.5)$ and the addition of $\mathrm{P}$ with $\mathrm{N}$ did not produce more insects than that from $\mathrm{N}$ alone $(p>0.7)$. Chironomids were the most common taxonomic group of the emerging adults, and the results for total numbers were heavily weighted by this group. Analysis of the chironomid data alone showed similar results. Date effects were significant $(p<0.001)$ and the date-by-treatment interaction was not significant $(p>0.5)$. $\mathrm{N}$ additions produced more animals than the control $(p<0.005)$ and there was no effect of $\mathrm{P}$ added alone $(p>0.1)$.

There was no change in taxonomic richness in the emergence with treatment (repeated measures ANOVA, $p>0.7$; Table 4). Although the control had fewest taxa after the first week of nutrient additions, it supported numbers of taxa that were within the range found in the troughs receiving the nutrients. For all treatments, however, there was a consistent and significant $(p<0.001)$ increase in richness through time, reaching an average of 8.3 taxa in the troughs receiving both $\mathrm{N}$ and $\mathrm{P}$ additions.

\section{Benthos}

Chironomid larvae were the most common insect group found in the mesocosm, with relative abundance of about $80 \%$ in control troughs to $85 \%$ in troughs receiving additions of $\mathrm{N}$ alone (Table 5). Chironomidae numbers were dominated by the subfamily Orthocladiinae, with lesser numbers of Tanypodinae and Tanytarsini. Pupal chironomids were also enumerated, but they were not identified beyond family. The mayflies represented $14.2 \%(\mathrm{~N}$ alone) to $18.3 \%$ (control) of the total numbers and mainly included Baetis sp., Ephemerella sp., and Serratella sp., the latter being most common in all treatments (Table 5). The stonefly and caddisfly numbers were only $0.1-0.5 \%$ of total benthic abundance, respectively (Table 5).

The addition of nutrients significantly increased total benthic density (Tables 5 and 6). The analysis was run independently for 11 taxa or groupings correcting for multiple comparisons (Table 6). The species tested in rank order by density for those species that occurred in numbers $>0.2$ animal per subsample tube or in six or more troughs are listed in Table 6. Most of the treatment response in total densities was due to significant increases in numbers of baetid mayflies
Table 2. Relative abundance (\% of total cell counts) of periphytic algal phyla or classes and relative abundance of diatom genera $(\%$ of total counts of diatom cells) on styrofoam substrata by treatment in the experimental troughs.

\begin{tabular}{lcccr}
\hline Taxonomic group & Control & $\begin{array}{c}\mathrm{N} \text { added } \\
\left(10 \mu \mathrm{g} \cdot \mathrm{L}^{-1}\right)\end{array}$ & $\begin{array}{c}\mathrm{P} \text { added } \\
\left(5 \mu \mathrm{g} \cdot \mathrm{L}^{-1}\right)\end{array}$ & $\begin{array}{r}\mathrm{N}+\mathrm{P} \\
\text { added }\end{array}$ \\
\hline Phylum or class & & & & \\
Bacillariophyceae & 82 & 88.4 & 79.5 & 86.3 \\
Chlorophyta & 16.3 & 10.5 & 20.0 & 12.5 \\
Cyanophyceae & 0.5 & 0.4 & 0.5 & 0.5 \\
Bacillariophyceae & & & & \\
Synedra sp. & 62.5 & 58.8 & 57.5 & 61.3 \\
Fragillaria spp. & 14.3 & 12.3 & 15.8 & 11.8 \\
Hannaea arcus & 7.8 & 15.5 & 12.5 & 21.3 \\
Tabellaria sp. & 10.8 & 11.5 & 9.8 & 3.3 \\
Other & 4.8 & 2.0 & 4.5 & 2.5 \\
\hline
\end{tabular}

Note: The "Other" group under Bacillariophyceae included Rhopalodia gibba, Cymbella sp., Nitzschia sp., Gomphonema sp., and Melosira varians. The chlorophytes included Oedogonium sp., Closterium sp., and Cosmarium sp. The only cyanophyte found was Anabaena sp.

(control versus $\mathrm{N}+\mathrm{P}$ addition, $p=0.005)$ and particularly the orthoclad chironomids (control versus $\mathrm{N}+\mathrm{P}$ addition, $p=$ $0.005)$. The Orthocladiinae were numerically the most abundant group (Table 5) and strongly influenced treatment contrasts for the entire community. Additions of $\mathrm{N}$ and $\mathrm{P}$ significantly increased total insect densities 1.73-fold and Orthocladiinae densities by 1.77 times. Additions of $\mathrm{N}$ alone increased total densities by 1.54 times and Orthocladiinae densities by 1.71 times. Total densities and Orthocladiinae densities were higher with $\mathrm{P}$ addition but not significantly so (Tables 5 and 6). Changes in numbers of chironomid pupae were particularly striking, with densities under $\mathrm{N}$ addition 1.7 times those of controls and $\mathrm{N}+\mathrm{P}$ additions resulting in 2.8 times higher densities. Even the addition of $\mathrm{P}$ increased numbers of pupae by 1.3 times. Numbers of Baetis sp. increased significantly only with combined $\mathrm{N}$ and $\mathrm{P}$ addition. Despite this change, numbers of Baetis sp. were only about $1 \%$ of the chironomid numbers and did not strongly influence treatment effects on total numbers. The mayfly Serratella sp. was the second most abundant taxon and treatment effects were ranked in the same order as that for the Orthocladiinae (Table 6), but variation among replicate troughs was high, resulting in no significant treatment effect. Responses by the remaining taxa generally indicated that the combination of $\mathrm{N}$ and $\mathrm{P}$ additions increased densities (Table 5), but responses to $\mathrm{N}$ or $\mathrm{P}$ alone were mixed and relative changes were small.

\section{Insect drift}

Drift of insects, i.e., emigration from the troughs, was measured for three 24-h periods during the course of the experiment. Using the same two-way, nested ANOVA design that was used to examine time effects in the emergence, a significant increase through time in numbers of Orthocladiinae and Serratella sp. and total numbers of all insects in drift was found (all $p<0.001$ ). Drift rates of the numerically dominant taxa (Orthocladiinae and Serratella sp.) and total numbers all increased between the first and last dates and most also increased between the first and second dates (Table 7). A large 
Table 3. Mean numbers by taxa and total numbers ( $\pm 1 \mathrm{SE}$ in parentheses) of emerging insects per trough enumerated from each treatment, and percentage of the total numbers represented by each taxonomic group.

\begin{tabular}{lcccc}
\hline Group & Control & $\mathrm{N}$ added & $\mathrm{P}$ added & $\mathrm{N}+\mathrm{P}$ added \\
\hline Ephemeroptera & $5.25(0.9), 3.5 \%$ & $5.25(1.3), 2.2 \%$ & $4.75(0.8), 3 \%$ & $4.25(1.3), 2 \%$ \\
Plecoptera & $6.75(1.1), 4.6 \%$ & $9.75(0.9), 4.1 \%$ & $11.5(1.2), 7.3 \%$ & $19.0(6.8), 8.8 \%$ \\
Trichoptera & $38.75(16.8), 26 \%$ & $29.75(1.0), 12.5 \%$ & $31.25(3.2), 20 \%$ & $34.5(9.7), 16 \%$ \\
Chironomidae & $89.5(22.7), 60.4 \%$ & $180.5(21.8), 76 \%$ & $98.75(12.3), 63 \%$ & $147.5(9.5), 68.4 \%$ \\
Other Diptera & $8(0.8), 5.4 \%$ & $12.5(2.9), 5.3 \%$ & $10.5(4.3), 6.7 \%$ & $10.5(4.6), 4.9 \%$ \\
Total & $148.25(38.3)$ & $237.75(24.5)$ & $156.75(12.8)$ & $215.75(13.5)$ \\
\hline
\end{tabular}

Fig. 3. Emergence rates of total numbers of insects per trough per week by day and treatment. Error bars are excluded for clarity.

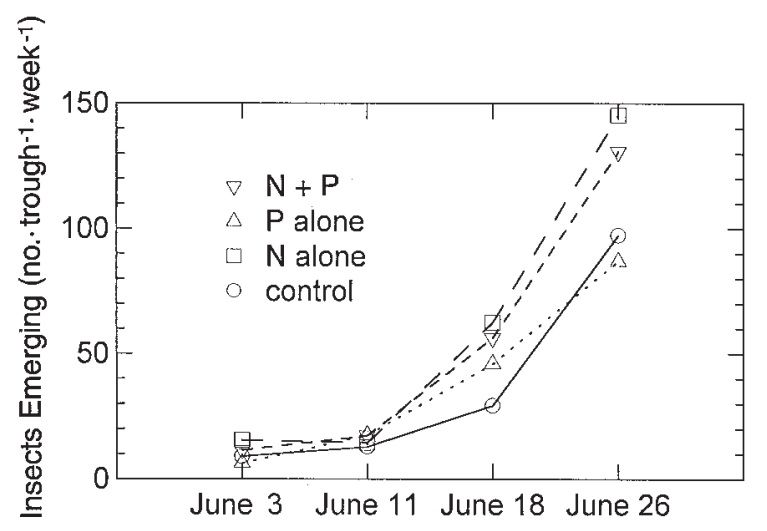

increase was found on June 26, the last day of the experiment when algal sloughing was also noticeable.

Because numbers of drifting larvae are positively related to benthos and thus increase with $\mathrm{N}$ and $\mathrm{N}+\mathrm{P}$ additions (Table 7), daily drift rates were normalized to benthic densities, by taxon, to determine per capita drift rates. Per capita drift rates were calculated for Orthocladiinae, Baetis sp., Serratella sp., total numbers, and taxonomic richness; these were the only groups and taxa for which there were sufficient numbers of individuals to run the analysis. In all cases, there were no significant per capita treatment effects on any group (all $p>$ 0.09), indicating that per capita drift of the Orthocladiinae, the mayflies, and total numbers did not change as a function of the nutrient addition.

\section{Discussion}

Addition of inorganic N, alone and in combination with $\mathrm{P}$, resulted in greatly increased accrual of periphyton and increased abundance of benthic macroinvertebrates in replicated mesocosms of the Nechako River benthic community. Findings of $\mathrm{N}$ deficiency in river periphyton that are not influenced by nutrient pollution are usually associated with the occurrence of volcanic parent materials (e.g., Bothwell 1992; Peterson and Grimm 1992) that contain more P compared with other formations. Exposed geology of the upper Nechako River, including extensive shorezones of Cheslatta Lake and Murray Lake and the upper $10 \mathrm{~km}$ of river, is typical in this regard, being characterized by volcanic andesite and basalt (Tipper 1962). Weathering of this material introduces dissolved $P$ into the river, and assimilation of the $\mathrm{P}$ by benthic algae would be expected to produce a relative demand for inorganic N. At the location of the trough mesocosms in the upper Nechako River,
Table 4. Mean taxonomic richness ( \pm 1 SE in parentheses) of insect emergence caught in traps above the mesocosm troughs through time for each treatment.

\begin{tabular}{lcccc}
\hline & June 3 & June 11 & June 18 & June 26 \\
\hline Control & $2.8(0.3)$ & $4.8(0.5)$ & $6.0(0.7)$ & $7.0(0.7)$ \\
N added & $5.3(0.6)$ & $4.5(0.9)$ & $5.3(1.4)$ & $6.8(0.6)$ \\
P added & $4.8(1.1)$ & $3.5(0.5)$ & $5.8(0.8)$ & $7.0(0.9)$ \\
N + P added & $4.3(1.1)$ & $5.5(0.9)$ & $6.5(0.9)$ & $8.3(1.0)$ \\
\hline
\end{tabular}

the unamended molar N:P supply ratio was estimated to be not less than 1.25 at high SRP concentrations in early June and 7.9 at the lower SRP concentrations in late June. The addition of $\mathrm{N}$ produced a greater periphyton biomass response than the addition of $\mathrm{P}$, thereby showing that at the low ambient $\mathrm{N}: \mathrm{P}$ supply ratios, accrual of the periphyton community was primarily $\mathrm{N}$ limited, a finding that was consistent with results of earlier tests of nutrient limitation in the upper Nechako River (Slaney et al. 1994). Unamended concentrations of soluble P were also low, however, and a further periphyton biomass response to the addition of $\mathrm{P}$ with $\mathrm{N}$ augmentation at only $10 \mu \mathrm{g} \cdot \mathrm{L}^{-1}$ was evidence of limitation by $\mathrm{P}$ when $\mathrm{N}$ was added. If $\mathrm{P}$ were in surplus, the addition of $\mathrm{P}$ would not have produced the further response in biomass accrual.

Although $\mathrm{N}$ limitation is often associated with relatively high concentrations of soluble $\mathrm{P}$ and the occurrence of algae that can fix $\mathrm{N}$, our data show that where both $\mathrm{N}$ and $\mathrm{P}$ concentrations were extremely low, $\mathrm{N}$-fixers were not favoured. This finding is similar to that reported by Suttle and Harrison (1988) for an oligotrophic coastal lake. They suggested that because many $\mathrm{N}$-fixers are poor competitors for available $\mathrm{P}$ compared with many other taxa, particularly diatoms, there is inadequate $\mathrm{P}$ available for $\mathrm{N}$-fixers to grow at rapid rates when both $\mathrm{N}$ and $\mathrm{P}$ are present in very low supply. The same rationale may be applied to the Nechako River. Diatoms were the most abundant taxonomic group in all treatments in the mesocosm, and with low $\mathrm{N}$ and $\mathrm{P}$ concentrations even in the troughs receiving nutrient additions, they remained the most abundant group of the periphyton community. Suboptimal concentrations of available $\mathrm{P}$ for $\mathrm{N}$-fixers may have been one factor preventing those taxa from becoming abundant at N-limited conditions.

Comparison of measured SRP and DIN concentrations with those known in the nutrient additions indicated that the periphyton were able to affect concentrations of SRP and DIN in water passing through the troughs. The depletion of $\mathrm{P}$ with additions of $\mathrm{N}$ (Table 1) was an effect likely due to $\mathrm{P}$ demand from the periphyton growth response to the added N. The same effect was noted during fertilization of the Nechako mainstem in 1989 (Slaney et al. 1994), when depletion of the added 
Table 5. Mean densities of groups and taxa (no. $\mathrm{m}^{-2}$ extrapolated from the area of each trough) ( \pm 1 SE in parentheses) in benthos collected from the four replicate mesocosms of each treatment on June 26.

\begin{tabular}{lcccc}
\hline Group or taxon & Control & N added & P added & N + P added \\
\hline Total numbers & $14835(1411)$ & $23051(1540)$ & $21113(2627)$ & $25870(2722)$ \\
Richness & $11(0.7)$ & $10(0.7)$ & $9.75(0.3)$ & $10.5(0.3)$ \\
Baetis sp. & $37.8(24.1)$ & $138(55.8)$ & $188.8(37.7)$ & $252(54.4)$ \\
Ephemerella sp. & $390.1(72.3)$ & $176.2(83.4)$ & $276.8(66.6)$ & $541(162.3)$ \\
Serratella sp. & $2315(356.5)$ & $2982(412.7)$ & $2680(404.9)$ & $3637(379.6)$ \\
Chloroperlidae & $75.5(32.5)$ & $25.2(14.5)$ & $25(14.5)$ & $76(43.6)$ \\
Hydropsychidae & $75.5(32.5)$ & $101(20.5)$ & $25(14.5)$ & $88(37.7)$ \\
Orthocladiinae & $10721(1053)$ & $18297(1308)$ & $16623(2339)$ & $18976(2066)$ \\
Tanypodini & $302(54.4)$ & $125.8(43.6)$ & $138(31.6)$ & $315(99.3)$ \\
Tanytarsini & $239(62.9)$ & $276.8(172.4)$ & $365(51.9)$ & $377(59.9)$ \\
Chironomid pupae & $566(113.2)$ & $893(172.4)$ & $717(148.7)$ & $1585(245.3)$ \\
\hline
\end{tabular}

Note: Total numbers include rarer taxa not included in the table.

fertilizer at downstream water sampling sites could only be explained by uptake related to a growth response by periphyton downstream of nutrient additions. In the mesocosm troughs, $\mathrm{N}$ was added as $\mathrm{NH}_{4} \mathrm{NO}_{3}$, which would have readily dissociated into $\mathrm{NO}_{3}{ }^{-}$and $\mathrm{NH}_{4}{ }^{+}$, potentially producing a maximum added concentration of each form of only $5 \mu \mathrm{g} \cdot \mathrm{L}^{-1}$. If effects of assimilation by the periphyton are also considered with background inorganic $\mathrm{N}$ concentrations that were below detection, it is not surprising that $\mathrm{NO}_{3}{ }^{-} \mathrm{N}$ and $\mathrm{NH}_{4}{ }^{+}-\mathrm{N}$ were never detected.

A typical event during time-course accrual of periphyton in rivers augmented with nutrients is a massive decline in biomass shortly after a logarithmic increase in biomass has occurred (Perrin et al. 1987) despite continuous enrichment. Results from the mesocosm were consistent with this process: biomass from the $\mathrm{N}+\mathrm{P}$ addition declined from a peak chlorophyll $a$ concentration of $62.4 \mathrm{mg} \cdot \mathrm{m}^{-2}$ to reach $10.5 \mathrm{mg} \cdot \mathrm{m}^{-2}$ within the final week of the experiment. Biomass from the $\mathrm{N}$ addition also declined abruptly from $24.4 \mathrm{mg} \cdot \mathrm{m}^{-2}$ to a final level of $6.2 \mathrm{mg} \cdot \mathrm{m}^{-2}$ despite continuous enrichment. The effect was due to sloughing of the attached biomass that was induced by what appeared as progressive senescence of biomass deep within the algal mat. Bothwell (1989) and Stevenson (1990) showed that mat density can affect algal growth by producing nutrient diffusion gradients between the outside and inside of mat biomass. Stevenson and Glover (1993) also showed that the physical structure of the algal mat can interfere with the flux of nutrients within the mat and that an increase in current velocity is required to avoid declining nutrient flux as mat size increases. Because current velocity did not change with nutrient addition to our mesocosm troughs, a nutrient diffusion gradient within the mat would have increased as algal mat size increased. We hypothesize that as this process continued, nutrient limitation of biomass accrual inside the mat became severe relative to that on the outside surface, potentially leading to massive sloughing as attachments to substrata weakened and finally released due to poor or no growth inside the mat.

A consistent finding from the enumeration of emerging insects and benthos was that manipulation of $\mathrm{N}$ concentration had a significant indirect effect on aquatic insects, either singly or in combination with $\mathrm{P}$. The positive correlation between periphyton response to nutrient addition and the insect responses suggests that insect densities are limited by the nutrient-limited production of periphyton in the Nechako River. Similar results have been found in other rivers in which nutrient augmentation has produced a functional response by grazing insects (McCormick and Stevenson 1991) and an increase in abundance of benthic invertebrates (Hart and Robinson 1990; Johnston et al. 1990; Mundie et al. 1991; Peterson et al. 1993). Together, these observations show that there can be a close coupling between periphyton biomass and benthic invertebrate abundance controlled by a limiting resource.

Insects that consume algae or fine particulate detritus were the predominant invertebrate groups in our study. Although the emerging chironomid adults were not keyed beyond family, the importance of the Orthocladiinae in both the benthos (Table 5) and drift (Table 7) suggests that the same subfamily would have been the main taxon in emergence traps. The Orthocladiinae and mayflies (e.g., Baetis sp.) derive their food by grazing algae or collecting particulate detritus, and diatoms are a particularly important food source for many of the taxa that responded to nutrient addition. We conclude that the increased algal biomass and detritus produced from algal growth and decomposition was the factor contributing to increased insect numbers in the mesocosm.

Previous studies of effects of enhanced food supply on aquatic insects suggest that increased numbers are partly due to improved survival of larvae (Mundie et al. 1991; Richardson and Neill 1991), and our study supports this conclusion. Change in survival rate is actually difficult to measure directly for invertebrates, and therefore, other lines of evidence are used to show effects on survival. Increases in benthic densities in experimental streams in response to food or nutrient supplementation in the absence of changes in emigration or immigration rates have been attributed to enhanced survival rate (Mundie et al. 1991; Richardson and Neill 1991). Increased patch residence time in patches with greater food resources can result in locally enhanced densities but also leads to reduced emigration rates (Kohler 1985). It is not clear whether there could be an interaction between increased benthic densities and the absence of fish predation within the mesocosms, although predaceous invertebrates were present in all troughs. Assuming that immigration rates did not differ between troughs, an increase in absolute numbers of emigrants and benthos as we observed in our experiment implies an increase in survival of immigrants. 
Table 6. Results of independent tests of orthogonal contrasts of treatment effects on total benthic density, richness, chironomid pupae, and eight taxa.

\begin{tabular}{lcccc}
\hline & \multicolumn{3}{c}{ Contrast (probability) } \\
\cline { 2 - 4 } Taxon or group & $\begin{array}{c}\text { Control versus } \\
\text { N addition }\end{array}$ & $\begin{array}{c}\text { Control versus } \\
\text { P addition }\end{array}$ & $\begin{array}{c}\text { Control versus } \\
\mathrm{N}+\text { P addition }\end{array}$ & Ranking \\
\hline Total numbers* & 0.01 & 0.035 & 0.002 & $4>2>3>1$ \\
Richness & 0.211 & 0.125 & 0.521 & $1>4>2>3$ \\
Baetis sp. & 0.114 & 0.024 & 0.005 & $4>3>2>1$ \\
Ephemerella sp. & 0.097 & 0.405 & 0.415 & $4>1>3>2$ \\
Serratella sp. & 0.209 & 0.471 & 0.03 & $4>2>3>1$ \\
Chloroperlidae & 0.237 & 0.237 & 0.964 & $4>1>2>3$ \\
Hydropsychidae & 0.504 & 0.211 & 0.761 & $2>4>1>3$ \\
Orthocladiinae* & 0.007 & 0.026 & 0.005 & $4>2>3>1$ \\
Tanypodinae & 0.044 & 0.063 & 0.986 & $4>1>3>2$ \\
Tanytarsini & 0.764 & 0.214 & 0.182 & $4>3>2>1$ \\
Chironomid pupae* & 0.168 & 0.485 & 0.003 & $4>2>3>1$ \\
\hline
\end{tabular}

Note: Critical $a$ for statistical significance was 0.005 after the Bonferroni correction for multiple comparisons (not including total numbers, which is a composite measure of all the others). An asterisk following the taxon or group name indicates that at least one contrast was significant. Rank numbers are based on least-square mean densities for treatments 1 (control), 2 ( $\mathrm{N}$ added alone), 3 (P added alone), and 4 ( $\mathrm{N}+\mathrm{P}$ added).

The invertebrate species that responded most to increased nutrient addition in our mesocosms are the same species that make up the diet of chinook young in the Nechako River. Stomach analyses of chinook fry captured in the same reach where the experiment was located and at the same time (Triton 1990) indicated that chironomids were the most common prey in the fry diet, followed by mayflies. Of 23 stomachs examined, the contents from 18 were predominately chironomids and six of those contained only chironomids. Given the increased abundance of chironomids and mayflies from increased algal growth, it is hypothesized that fertilization of the Nechako River can potentially lead to increased availability of important food organisms for chinook. Increased fish growth by as much as $100 \%$ resulted from nutrient addition to the Keogh River on Vancouver Island (Johnston et al. 1990) and to the Kuparuk River, Alaska (Deegan and Peterson 1992). In the Alaskan study, the response of Arctic grayling (Thymallus arcticus) occurred concurrently with accelerated development and increased body size of midges (Hershey et al. 1988), a common diet organism of this fish. Close linkages between autotrophic response to nutrient manipulation and fish growth have indicated that nutrient limitation in streams affects the higher trophic levels (Johnston et al. 1990; Deegan and Peterson 1992). The inability of Slaney et al. (1994) to detect this response during mainstem fertilization of the Nechako River in 1989 was probably due to factors other than food supply that affected measures of the chinook response. Slaney et al. (1994) noted that juvenile chinook were highly mobile in the upper Nechako River when the fertilization occurred, suggesting that fish movement was an important factor in confounding measurement of a fish response to fertilization.

The relatively high numbers of chironomids in the mesocosm lead to the question whether mesocosms select for this taxon in short-term experiments. The taxa found in this experiment typically occupy riffles, and their presence suggests that the mesocosm had riffle characteristics despite the low surface velocity of $5 \mathrm{~cm} \cdot \mathrm{s}^{-1}$. Mundie et al. (1991) suggested that uniform-sized gravel, which was used in this experiment, presents large subsurface spaces that allow rapid water movement and enhance riffle characteristics even when surface velocities are low. In lasting only 5 weeks, an important reason that chironomids were common is that many develop rapidly and have short life cycles (Stites and Benke 1989; Mundie et al. 1991), which is amenable to short-term experiments. Mundie et al. (1991) used similar troughs but allowed 4 weeks for the troughs to be colonized before nutrient addition and the experiment continued for an additional 7 weeks. Despite this longer duration, chironomids remained the most abundant taxon. Chironomids were also a major component of the benthic community during whole-river fertilization of the $\mathrm{Ku}$ paruk River (Hershey et al. 1988), and the Keogh River (Johnston et al. 1990). Although an experiment of much longer duration and larger scale than the present one is required to examine temporal shifts in community structure, evidence to date suggests that chironomids are functionally important in river food webs in both short-term and longer-term community development with and without nutrient manipulations. Hence, results from the mesocosm experiment are considered representative of changes in Nechako River benthos to be expected from additions of nutrients.

Two related scale issues affect the interpretation of this experiment. These are the degree to which algal herbivore dynamics are coupled and the duration of nutrient additions relative to the generation time of herbivores. One might expect the increased grazer abundances typically observed in nutrient addition experiments to limit the accrual of algal biomass. There are many examples where grazers at high densities reduce periphyton biomass (e.g., Lamberti and Resh 1983; Jacoby 1985) even with nutrient additions (McCormick and Stevenson 1991; Bothwell and Culp 1993). There are also many conditions under which such coupling of the productivities of producer and consumer may not keep pace with each other (e.g., Murdoch and McCauley 1985). For example, in the whole-river fertilization of the Keogh River (Perrin et al. 1987) and the Nechako River (Slaney et al. 1994), algal biomass increased by several times during the first few weeks of fertilization in spite of increased densities of grazing insects. In the Keogh River, the increase in algal biomass was followed 
Table 7. Mean 24-h drift rates (no. drifting $24 \mathrm{~h}^{-1} \cdot$ trough $\left.^{-1}\right)( \pm 1 \mathrm{SE}$ in parentheses) from mesocosm troughs by day and treatment for Serratella sp., Orthocladiinae, and total insect numbers.

\begin{tabular}{llrrr}
\hline Taxon or group & & June 11 & June 18 & June 26 \\
\hline Serratella sp. & Control & $3.3(0.9)$ & $10.8(4.5)$ & $50.8(6.8)$ \\
& N added & $5.5(3.3)$ & $7.3(2.4)$ & $72.9(17.5)$ \\
& P added & $2.7(1.2)$ & $9.8(1.9)$ & $50.8(12.8)$ \\
Orthocladiinae & N + P added & $4(0.7)$ & $13.5(3.6)$ & $48.9(8.2)$ \\
& Control & $2.3(0.5)$ & $1.5(0.9)$ & $39.7(10.0)$ \\
& N added & $3.5(1.8)$ & $5.5(2.5)$ & $140.3(51.1)$ \\
& P added & $4(1.2)$ & $8.5(4.7)$ & $52.6(15.8)$ \\
Total & N + P added & $2.8(0.6)$ & $17.3(1.9)$ & $167.1(37.9)$ \\
& Control & $32.3(5.0)$ & $30.1(6.5)$ & $274.2(24.3)$ \\
& N added & $30(8.4)$ & $31.3(2.8)$ & $375.7(104.0)$ \\
& P added & $38.3(4.1)$ & $37.8(3.1)$ & $326.8(51.5)$ \\
& N + P added & $26.3(8.2)$ & $53.5(7.2)$ & $459.7(68.3)$ \\
\hline
\end{tabular}

by massive sloughing of periphyton after which algal biomass never returned to high densities. This longer-term change in algal response may in part be related to a time lag effect of increasing grazer survival on the ability of grazers to crop algal biomass to low levels after an initial phase of rapid periphyton accrual (Perrin et al. 1987). These observations suggest that grazers have a slower change in density and biomass in response to change in algal biomass compared with the rate at which algae can respond to nutrient addition. These differences in rates may offset a coupling between producers and consumers in short time series of observations.

In longer-term whole river experiments, overwinter survival or other factors limiting density such as space or predation may influence relationships between the duration of fertilization and change in density and generation time of insects. Increased densities of invertebrates in response to enhanced algal production in spring and summer show that at least some species are food limited at that time of year. During the Kuparak River fertilization, algal biomass increased for the first 2 years of treatment during the ice-free period in spite of increases in insect densities, and it was only by the third year of treatment that insect densities had increased to an extent that periphyton biomass was apparently regulated by consumers (Peterson et al. 1993). In the Keogh River study, this control of periphyton biomass by invertebrates was not observed despite several years of summer-only fertilization (Johnston et al. 1990). Reasons for these differences most likely relate to river-specific conditions limiting consumer density at times of the year when fertilizer is not added. In the Alaskan study, nutrient addition lasted for most of the ice-free period. The benthic community was then frozen in place for the winter period which is potentially important for maintaining densities into the following spring (Peterson et al. 1993). In the Keogh River, increases in invertebrate densities during fertilization in spring and summer may have been offset by high flows in winter which are capable of moving bedload (Johnston et al. 1990). It can be hypothesized that these winter flows act as a reset mechanism that inhibits carryover of responses from fertilization to subsequent years. While the present mesocosmscale experiment has revealed evidence of "bottom-up" control of fish food organism abundance in the Nechako River during short-term fertilization, these comparisons of long-term responses to fertilization in other rivers indicate that larger spatial- and temporal-scale experiments are necessary to determine actual change in availability of food organisms for fish and to determine change in the coupling between producers and consumers in a system of increased productivity.

\section{Acknowledgements}

This work was funded by the Nechako Fisheries Conservation Program which is jointly managed by the Department of Fisheries and Oceans, the Province of British Columbia, and Alcan Ltd. The authors gratefully acknowledge assistance in the field provided by Rick Irvine and Carl Paton. We thank Bert and Mary Irvine for their hospitality and for allowing access through their property on the Nechako River. Assistance and cooperation from Bill Rublee, Harry Goldberg, and other field staff of Triton Environmental Consultants are greatly appreciated. We are grateful for numerous technical discussions with Pat Slaney of the British Columbia Fisheries Branch during all phases of the project. Karen Needham completed the enumeration and identification of the aquatic invertebrates and Mary Bolin identified and enumerated the algae. We appreciate comments on the manuscript by the referees and representatives of the Nechako Fisheries Conservation Program.

\section{References}

Bothwell, M.L. 1989. Phosphorus-limited growth dynamics of lotic periphyton diatom communities: areal biomass and cellular growth rate responses. Can. J. Fish. Aquat. Sci. 46: 1293-1301.

Bothwell, M.L. 1992. Eutrophication of rivers by nutrients in treated kraft mill effluent. Water Pollut. Res. J. Can. 27: 447-472.

Bothwell, M.L., and Culp, J.M. 1993. Sensitivity of the Thompson River to phosphorus: studies on trophic dynamics. Nat. Hydrol. Res. Cent. Contrib. No. 93006.

Bradford, M.J. 1994. Trends in the abundance of chinook salmon (Oncorhynchus tshawytscha) of the Nechako River, British Columbia. Can. J. Fish. Aquat. Sci. 51: 965-973.

Deegan, L.A., and Peterson, B.J. 1992. Whole-river fertilization stimulates fish production in an Arctic tundra river. Can. J. Fish. Aquat. Sci. 49: 1890-1901.

Hart, D.D., and Robinson, C.J. 1990. Resource limitation in a stream community: phosphorus enrichment effects on periphyton and grazers. Ecology, 71: 1494-1502.

Healey, F.P. 1985. Interacting effects of light and nutrient limitation 
on the growth rate of Synechococcus linearis (Cyanophyceae). J. Phycol. 21: 134-146.

Hershey, A.E., Hiltner, A.L., Hullar, M.A.J., Miller, M.C., Vestal, J.R., Lock, M.A., Rundle, S., and Peterson, B.J. 1988. Nutrient influence on a stream grazer: Orthocladius microcommunities respond to nutrient input. Ecology, 69: 1383-1392.

Holm-Hansen, O., Lorenzen, C.J., Holmes, R.W., and Strickland, J.D.H. 1965. Fluorometric determination of chlorophyll. J. Cons. Cons. Int. Explor. Mer, 30: 3-15.

Jacoby, J.M. 1985. Grazing effects on periphyton by Theodoxus fluviatilis (Gastropoda) in a lowland stream. J. Freshwater Ecol. 3: 265-274.

Johnston, N.T., Perrin, C.J., Slaney, P.A., and Ward, B.R. 1990. Increased juvenile salmonid growth by whole-stream fertilization. Can. J. Fish. Aquat. Sci. 47: 862-872.

Kohler, S.L. 1985. Identification of stream drift mechanisms: an experimental and observational approach. Ecology, 66: 1749-1761.

Lamberti, G.A., and Resh, V.H. 1983. Stream periphyton and insect herbivores: an experimental study of grazing by a caddisfly population. Ecology, 61: 1124-1135.

McCormick, P.V., and Stevenson, R.J. 1991. Grazer control of nutrient availability in the periphyton. Oecologia, 86: 287-291.

Mundie, J.H., McKinnell, S.M., and Traber, R.E. 1983. Responses of stream zoobenthos to enrichment of gravel substrates with cereal grain and soybean. Can. J. Fish. Aquat. Sci. 40: 1702-1712.

Mundie, J.H., Simpson, K.S., and Perrin, C.J. 1991. Responses of stream periphyton and benthic insects to increases in dissolved inorganic phosphorus in a mesocosm. Can. J. Fish. Aquat. Sci. 48: 2061-2072.

Murdoch, W.W., and McCauley, E. 1985. Three distinct types of dynamic behaviour shown by a single planktonic system. Nature (London), 316: 628-630.

Nusch, E.A. 1980. A comparison of different methods for chlorophyll and pheopigment analysis. Ergeb. Limnol. 14: 14-36.

Perrin, C.J., Bothwell, M.L., and Slaney, P.A. 1987. Experimental enrichment of a coastal stream in British Columbia: effects of organic and inorganic additions on autotrophic periphyton production. Can. J. Fish. Aquat. Sci. 44: 1247-1256.

Perrin, C.J., Wilkes, B., and Richardson, J.S. 1992. Stream periphyton and benthic insect responses to additions of treated acid mine drainage in a continuous-flow on-site mesocosm. Environ. Toxicol. Chem. 11: 1513-1525.

Peterson, C.G., and Grimm, N.B. 1992. Temporal variation in enrichment effects during periphyton succession in a nitrogen-limited desert stream ecosystem. J. N. Am. Benthol. Soc. 11: 20-36.
Peterson, B.J., Hobbie, J.E., Corliss, T.L., and Kriet, K. 1983. A continuous-flow periphyton bioassay: tests of nutrient limitation in a tundra stream. Limnol. Oceanogr. 28: 583-591.

Peterson, B.J., Hobbie, J.E., Hershey, A.E., Lock, M.A., Ford, T.E., Vestal, J.R., McKinley, V.L., Hullar, M.A.J., Miller, M.C., Volk, R.M., and Ventullo, G.S. 1985. Transformation of a tundra river from heterotrophy to autotrophy by addition of phosphorus. Science (Washington, D.C.), 229: 1383-1386.

Peterson, B.J., Deegan, L., Helfrich, J., Hobbie, J.E., Hullar, M.A.J., Moller, B., Ford, T.E., Hershey, A.E., Hiltner, A., Kipphut, G., Lock, M.A., Fiebig, D.M., McKinley, V., Miller, M.C., Vestal, J.R., Ventullo, R.M., and Volk, G.S. 1993. Biological responses of a tundra river to fertilization. Ecology, 74: 653-672.

Rhee, G.-Y., and Gotham, I.J. 1980. Optimum N:P ratios and coexistence of planktonic algae. J. Phycol. 16: 486-489.

Richardson, J.S., and Neill, W.E. 1991. Indirect effects of detritus manipulations in a montane stream. Can. J. Fish. Aquat. Sci. 48: 776-783.

Richardson, J.S., and Perrin, C.J. 1994. Effects of the bacterial insecticide, Bacillus thuringiensis var. kurstaki (Btk), on a stream benthic community. Can. J. Fish. Aquat. Sci. 51: 1037-1045.

Slaney, P.A., Rublee, B.O., Perrin, C.J., and Goldberg, H. 1994. Debris structure placements and whole-river fertilization for salmonids in a large regulated stream in British Columbia. Bull. Mar. Sci. 55: 1160-1180.

Stevenson, R.J. 1990. Benthic algae community dynamics in a stream during and after a storm. J. N. Am. Benthol Soc. 9: 277-288.

Stevenson, R.J., and Glover, R. 1993. Effects of algal density and current on ion transport through periphyton communities. Limnol. Oceanogr. 38: 1276-1281.

Stites, D.L., and Benke, A.C. 1989. Rapid growth rates of chironomids in three habitats of a subtropical river and their implications for $P: B$ ratios. Limnol. Oceanogr. 34: 1278-1289.

Suttle, C.A., and Harrison, P.J. 1988. Ammonium and phosphate uptake rates, $\mathrm{N}: \mathrm{P}$ supply ratios, and evidence for $\mathrm{N}$ and $\mathrm{P}$ limitation in some oligotrophic lakes. Limnol. Oceanogr. 33: 186-202.

Tipper, H.W. 1962. Nechako River geology. Memoir 324 and cartography mapsheet 1131A. Geological Survey of Canada, Map and Publication Sales, 100 West Pender Street, Vancouver, BC V6V 1R8, Canada.

Triton. 1990. Assessment of fertilization in the Nechako River. Rep. No. RM90-5. Prepared for Nechako Fisheries Conservation Program by Triton Environmental Consultants, Richmond, B.C. 